\title{
Reactive co-sputter deposition of nanostructured cermet anodes for solid oxide fuel cells
}

\author{
Igor V. Ionov ${ }^{1,2 *}$, Andrey A. Solovyev ${ }^{1,2}$, Anna V. Shipilova ${ }^{2}$, Alexey M. Lebedynskiy ${ }^{1}$, \\ Egor A. Smolyanskiy ${ }^{1}$, Alexander L. Lauk ${ }^{1}$, and Vyacheslav A. Semenov ${ }^{2}$ \\ ${ }^{1}$ National Research Tomsk Polytechnic University, Tomsk 634050, Russia \\ ${ }^{2}$ Institute of High Current Electronics, Tomsk 634055, Russia \\ *E-mail: ionovigor@gmail.com
}

Received April 7, 2017; revised August 24, 2017; accepted September 5, 2017; published online November 21, 2017

The impact of a nanostructured $\mathrm{NiO} / \mathrm{yttria-stabilized} \mathrm{zirconia} \mathrm{(NiO/YSZ)} \mathrm{and} \mathrm{NiO/gadolinia-doped} \mathrm{ceria} \mathrm{(NiO/GDC)} \mathrm{anode} \mathrm{functional} \mathrm{layers} \mathrm{on}$ low- and intermediate-temperature solid oxide fuel cell (SOFC) performance is investigated. NiO/YSZ and NiO/GDC thin films were reactively sputter-deposited by pulsed direct current magnetron sputtering from the $\mathrm{Ni}, \mathrm{Zr}-\mathrm{Y}$, and $\mathrm{Ce}-\mathrm{Gd}$ targets onto commercial NiO/YSZ substrates. Anode-supported SOFCs based on magnetron sputtered YSZ and GDC electrolytes ( 4 $\mu \mathrm{m})$ with and without the nanostructured anode layers are fabricated. A direct comparison of the YSZ- and GDC-based SOFCs in temperature range of $600-800$ and $400-600{ }^{\circ} \mathrm{C}$ is made. The performance of cells with the nanostructured anode layers significantly increases as compared to that of the cell without it, especially at lower temperatures. Increase of cells performance was achieved by reduction of the total area-specific resistance by $26-30 \%$.

(C) 2018 The Japan Society of Applied Physics

\section{Introduction}

Solid oxide fuel cells (SOFCs) offer a promising technique for producing electricity by clean energy conversion through an electrochemical reaction of fuel and air. However, the high operating temperature of SOFCs $\left(700-1000^{\circ} \mathrm{C}\right)$ has limited the deployment of this technology due to degradation of SOFCs' characteristics over time and to poor reliability. By lowering working temperature, unwanted chemical reactions, interdiffusion of elements and corrosion of the interconnectors can be avoided. To maintain power output at lowered temperatures, new materials must be used, but their choice is very limited. Furthermore, the electrode performance of SOFCs deteriorates significantly with decreasing operating temperature. The electrode activity of SOFCs is strongly affected by its microstructural characteristics, such as porosity, grain size, and connectivity. ${ }^{1,2)}$ In this regard, nanostructured electrodes and thin film interlayers have been actively studied and improvements of SOFC performance have been reported. ${ }^{3-5)}$ Since nanostructured electrodes have enlarged surface area of the catalyst, they have an increased rate of electrode reaction, which reduces the polarization resistance at the electrodes at low temperatures. ${ }^{6,7)}$ Although the main limiting factor in SOFC performance at $700^{\circ} \mathrm{C}$ is the cathode overpotential, ${ }^{8)}$ nanostructured anode functional layers (AFL) also have been actively studied over the past decade. ${ }^{4)}$

Standard methods such as screen-printing or slip-casting are not suitable for nanostructured electrode formation, because the particle size obtained from conventional powder processing is on the order of micrometers due to coarsening during high-temperature sintering. Therefore, nanostructured SOFC anodes are usually produced by sputtering ${ }^{9-13)}$ or pulsed laser deposition (PLD). ${ }^{14,15)}$ In all aforecited works, $\mathrm{Ni}$ /yttria-stabilized zirconia (Ni/YSZ) is used as anode material, because it is considered as a standard anode for SOFCs. Tanveer et al. ${ }^{16)}$ prepared Ni/samaria-doped-ceria (Ni/SDC) cermet anodes on scandia-stabilized zirconia electrolyte substrates via radio-frequency (RF) sputtering. Peak power densities of single cells with a sputtered anode and a screen-printed LSM/YSZ cathode were 240, 140, and $50 \mathrm{~mW} / \mathrm{cm}^{2}$ at 800,700 , and $600^{\circ} \mathrm{C}$, respectively. $\mathrm{Ni}$ / gadolinia-doped ceria (Ni/GDC) thin film anodes were prepared by spray pyrolysis and pulsed laser deposition. ${ }^{17)}$ The polarization resistances were 1.73 and $0.68 \Omega \cdot \mathrm{cm}^{2}$ for the spray pyrolysis and PLD anode, respectively, at $600{ }^{\circ} \mathrm{C}$.

In this study, we investigated the electrochemical properties of anode-supported SOFCs with magnetron sputtered $\mathrm{Ni} / \mathrm{GDC}$ and $\mathrm{Ni} / \mathrm{YSZ}$ composite anode functional layers introduced into anode/electrolyte interface. As far as we know, Ni/GDC nano-grained thin film AFLs were never obtained by magnetron sputtering method. In contrast to YSZ, GDC is the usual choice for intermediate-temperature SOFCs $\left(600-800^{\circ} \mathrm{C}\right)$ due to its higher ionic conductivity in this range of temperatures. ${ }^{18)}$ Moreover, ceria-based materials present better catalytic and electrocatalytic activities for reforming and oxidation of hydrocarbons and hydrogen at lower temperatures. ${ }^{19)}$

\section{Experimental methods}

To study the influence of nanoscale AFL on SOFCs' performance, single cells with and without nano-AFL were fabricated. A $2 \mathrm{~cm}$ in diameter and 0.4-mm-thick NiO/YSZ anode supports cut out by laser from commercial anode sheets (Ningbo SOFCMAN Energy Technology) were used as substrates for magnetron deposition of both $\mathrm{NiO} / \mathrm{GDC}$ and $\mathrm{NiO} / \mathrm{YSZ}$ anode functional layers. AFLs were deposited by reactive magnetron co-sputtering of $\mathrm{Ni}$ ( $99.995 \%$ purity), $\mathrm{Zr}_{0.86} \mathrm{Y}_{0.14}$ and $\mathrm{Ce}_{0.9} \mathrm{Gd}_{0.1}$ targets with diameter of $75 \mathrm{~mm}$. Sputtering was carried out in oxygen-argon atmosphere at working pressure of $0.2 \mathrm{~Pa}$, using a pulse bipolar magnetron supply (Applied Electronics APEL-M-BP) at pulse repetition frequency of $75 \mathrm{kHz}$ and the positive pulse duration of $4 \mu \mathrm{s}$. Targets were positioned at $45^{\circ}$ to the fixed substrate holder. The distance between the magnetron target center and substrate was $80 \mathrm{~mm}$. Prior to film deposition, the substrates were heated to $400{ }^{\circ} \mathrm{C}$. After that the substrate surface was cleaned for $30 \mathrm{~s}$ by the ion beam generated by the ion source with a closed electron drift with $1000 \mathrm{~V}$ discharge voltage and $15 \mathrm{~mA}$ discharge current to improve the film adhesion. 
The deposited AFLs samples were annealed in air atmosphere at different temperatures $\left(600-1200^{\circ} \mathrm{C}\right)$ for $1 \mathrm{~h}$. The heating and cooling rate of samples during postannealing was $3{ }^{\circ} \mathrm{C} / \mathrm{min}$.

For a good thermo-mechanical compatibility with the electrolyte, the cells with $\mathrm{NiO} / \mathrm{GDC}$ AFL were tested with GDC electrolyte, while cells with $\mathrm{NiO} / \mathrm{YSZ}$ AFLs were tested with YSZ electrolyte. 4- $\mu$ m-thick electrolyte layers were also deposited by reactive magnetron sputtering. The details of this process were described in our previous work. ${ }^{20}$

The LSCF/GDC cathode layer was prepared on all cells by a screen-printing method using $\mathrm{La}_{0.6} \mathrm{Sr}_{0.4} \mathrm{Co}_{0.2} \mathrm{Fe}_{0.8} \mathrm{O}_{3} /$ $\mathrm{Ce}_{0.9} \mathrm{Gd}_{0.1} \mathrm{O}_{2}$ paste (CERA-FC). The cathode area was $1 \mathrm{~cm}^{2}$. Cathode sintering was performed at a temperature of $800{ }^{\circ} \mathrm{C}$ for $1 \mathrm{~h}$ before the fuel cell electrochemical test. Electrochemical tests were performed using ProboStat ${ }^{\mathrm{TM}}$ device (NorECs). The details about the single cell test bench and testing procedures are given in our previous work. ${ }^{21)}$ All sample preparations and analyses have been repeated at least twice.

The reduction-oxidation (redox) stability of $\mathrm{NiO} / \mathrm{GDC}$ AFL was investigated at $600^{\circ} \mathrm{C}$. Ten redox cycles were carried out manually by abruptly shutting down the $\mathrm{H}_{2}$ gas flow for $45 \mathrm{~min}$ and re-reducing for $30 \mathrm{~min}$. The anode was re-oxidated by the back-diffusion of oxygen from the atmosphere. During the re-oxidation step, the cell voltage decreased to less than $0.1 \mathrm{~V}$. The flow of the cathode air was not interrupted during the experiment. After reduction, current-voltage curves were measured in order to determine the amount of degradation caused by redox cycling.

The scanning electron microscope (SEM; FEI Quanta 3D 200) was used to study the surface and cross section of the deposited layers and to determine their thickness as well. For structural and phase analysis, some films were deposited on $\mathrm{Si}$ substrates. The $\mathrm{Ni}$ and $\mathrm{NiO}$ content in the film was determined by energy dispersive spectroscopy (EDAX; Pegasus 4000) and/or X-ray diffractometry (Shimadzu XRD-6000 with $\mathrm{Cu} \mathrm{K} \alpha$ radiation).

\section{Results and discussion}

The change of the $\mathrm{NiO}$ content in the deposited AFLs was realized by varying the oxygen flow rate and power of $\mathrm{Ni}$ magnetron $(300-800 \mathrm{~W})$ at constant argon flow rate $(30$ sccm) and power of $\mathrm{Zr}-\mathrm{Y}(1500 \mathrm{~W})$ and $\mathrm{Ce}-\mathrm{Gd}(1000 \mathrm{~W})$ magnetron. Since reactive magnetron deposition makes it difficult to maintain process parameters unchanged over time due to a hysteresis effect, ${ }^{22)}$ films deposition was conducted in oxide mode of sputtering. In this regime, at relatively high oxygen flow rates, the target surface is covered by oxide layer, and film deposition rate is relatively small. However, deposited films have a composition close to stoichiometric, so the deposition regimes have good reproducibility.

The NiO/YSZ film composition in dependence of $\mathrm{Ni}$ magnetron power and oxygen flow rate was studied by us earlier. ${ }^{23)}$ The Ni content in the film increases with increasing $\mathrm{Ni}$ magnetron power or decreasing oxygen flow rate. Deposition of $\mathrm{NiO} / \mathrm{GDC}$ film was realized at oxygen flow rate of $32 \mathrm{sccm}$ and at $\mathrm{Ni}$ magnetron power of 600,700 , and $800 \mathrm{~W}$. The energy dispersive spectroscopy results show that the films deposited in these regimes contain 23, 34, and 40 at. $\% \mathrm{Ni}$, respectively. The deposition rate of $\mathrm{NiO} / \mathrm{YSZ}$

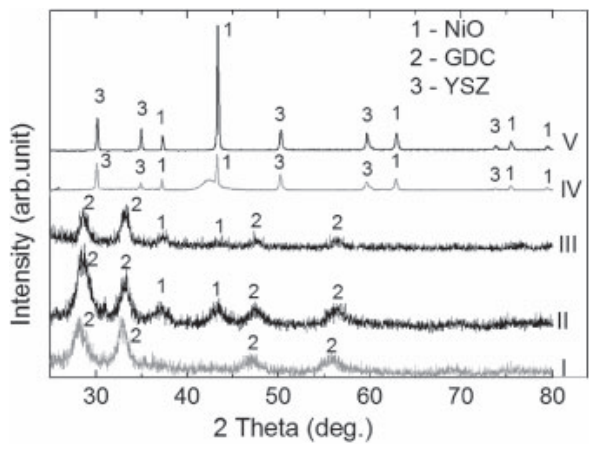

Fig. 1. XRD pattern of the magnetron sputtered $\mathrm{NiO} / \mathrm{GDC}$ (I-III) and $\mathrm{NiO} / \mathrm{YSZ}$ (IV-V) films after annealing: I - as-deposited, II $-600^{\circ} \mathrm{C}$, III $-900^{\circ} \mathrm{C}, \mathrm{IV}$ - as-deposited, V $-1200^{\circ} \mathrm{C}$.

and $\mathrm{NiO} / \mathrm{GDC}$ films in oxide mode of sputtering was about 2 and $3 \mu \mathrm{m} \cdot \mathrm{h}^{-1}$, respectively.

Figure 1 presents X-ray diffraction (XRD) patterns of asdeposited and annealed $\mathrm{NiO} / \mathrm{YSZ}(\mathrm{NiO} 66 \mathrm{vol} \%$ ) and $\mathrm{NiO} /$ GDC (Ni 34 at. \%) films. The intensity of diffraction peaks from $\mathrm{NiO} / \mathrm{GDC}$ film is lower because in this case measurements were conducted with a fixed grazing angle of incidence. It can be seen that both AFLs after deposition exhibit a crystalline structure with clear indicated peaks. Asdeposited NiO/YSZ AFL consists of a tetragonal phase of YSZ and nickel oxide with an unidentified peak at $42.44^{\circ}$ (curve IV). Annealing of the $\mathrm{NiO} / \mathrm{YSZ}$ AFL in air at $1200^{\circ} \mathrm{C}$ for $1 \mathrm{~h}$ leads to the disappearance of the unknown phase peak (curve V). As-deposited NiO/GDC AFL consists of the crystalline GDC phase only. Nickel oxide in as-deposited film is apparently in an amorphous state. After annealing at 600 and $900{ }^{\circ} \mathrm{C} \mathrm{Ni}$ oxide transforms into a crystal form as evidenced by the appearance of $\mathrm{NiO}$ phase peaks on the diffractogram (curves II and III). XRD data revealed no peaks of secondary phases, i.e., there is no obvious peaks from phases other than $\mathrm{NiO}$ and GDC until the detection limit of the XRD. NiO and GDC phases exhibit cubic structures with crystallite size of 23 and $45 \mathrm{~nm}$, respectively.

Figure 2(a) shows that after reduction of NiO/YSZ films in hydrogen $\left(800^{\circ} \mathrm{C}, 2 \mathrm{~h}\right)$ without pre-annealing in air $\mathrm{Ni}$ segregation and the formation of massive $\mathrm{Ni}$ agglomerates are observed on the film surface. Growth of Ni agglomerates is related to free surface energy minimization, and the driving force for $\mathrm{Ni}$ coarsening is extremely high in the case of nickel-containing films with extremely small (tens of $\mathrm{nm}$ ) size of crystallites. ${ }^{15)}$ Massive agglomerates of $\mathrm{Ni}$ were already observed on the surface of nanostructured Ni/YSZ films. ${ }^{17,24)}$ Coarsening of the Ni phase is usually attributed to Ostwald ripening phenomena. ${ }^{25)}$ The potential mechanism for the Ostwald ripening phenomena is transport of volatile $\mathrm{Ni}$ species via the gas phase (evaporation and precipitation). It is known from literature that $\mathrm{Ni}(\mathrm{OH})_{2}(\mathrm{~g})$ is the most volatile species in a gas mixture of $\mathrm{H}_{2}$ and $\mathrm{H}_{2} \mathrm{O} .{ }^{26}$ ) Thus, when starting with a dry gas of $\mathrm{H}_{2}$ the partial pressure of gaseous Ni-species is small. But it increases rapidly after the formation of even small quantities of water vapor due to electrochemical reaction. It is also well known from steamreforming nickel catalysts, that the surface diffusion of $\mathrm{Ni}$ (diffusion of Ni-hydroxide complexes) is strongly enhanced by humidity. This may play an important role for the grain 


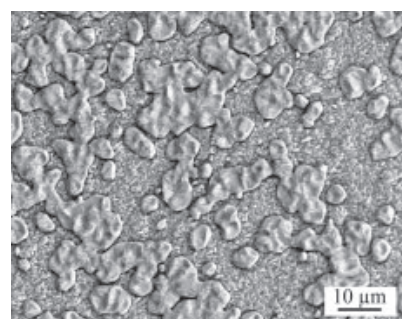

(a)

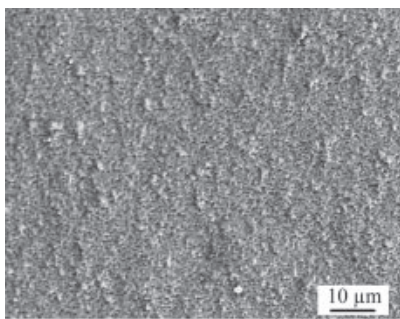

(b)
Fig. 2. Surface morphology of $\mathrm{NiO} / \mathrm{YSZ}(\mathrm{NiO} 60 \mathrm{vol} \%)$ films obtained after reduction in hydrogen at $800^{\circ} \mathrm{C}$ without pre-annealing in the air (a) and with pre-annealing in the air at $1200^{\circ} \mathrm{C}(\mathrm{b})$.

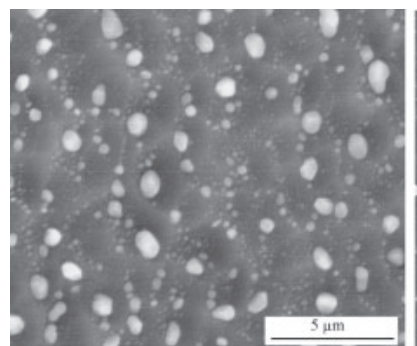

(a)

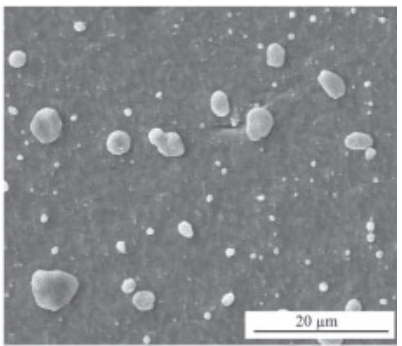

(b)

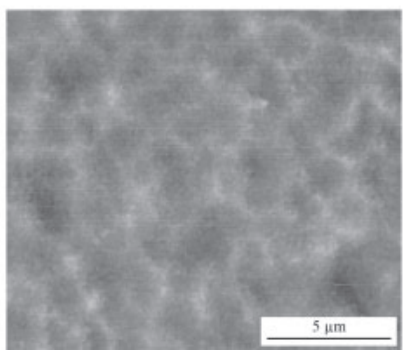

(c)

Fig. 3. Surface morphology of $\mathrm{NiO} / \mathrm{GDC}$ (Ni 34 at. \%) films obtained after reduction in hydrogen at $600{ }^{\circ} \mathrm{C}$ with pre-annealing in the air at 600 (a), 900 (b), and $1200^{\circ} \mathrm{C}$ (c).

growth of Ni in SOFC anodes. ${ }^{27)}$ The growth of Ni grains is connected with the corresponding reduction of the triplephase boundary (TPB) length and the electrochemical performance of the anode. ${ }^{28,29)}$ TPB is the electrochemically active area in the composite anodes where fuel oxidation reaction takes place and, therefore, it has crucial importance for the performance of solid-oxide fuel cells. ${ }^{30)}$

To solve the Ni agglomeration problem in NiO/YSZ films deposited by pulsed laser deposition Noh et al. ${ }^{15)}$ proposed to use annealing of these films in air at $1200^{\circ} \mathrm{C}$. It was shown that preliminary annealing prevents $\mathrm{Ni}$ agglomeration due to the formation of a stronger "skeleton" of YSZ granules, which prevents the coarsening of the Ni granules. Figure 2(b) shows that this method is very effective for suppression of the $\mathrm{Ni}$ agglomeration.

In Figs. 3(a)-3(c), the surface morphologies of NiO/GDC films obtained by the reduction of pre-annealed at 600, 900, and $1200^{\circ} \mathrm{C} \mathrm{NiO} / \mathrm{GDC}$ films are displayed. It is clear that the extent of the $\mathrm{Ni}$ agglomeration depends on annealing temperature. As shown in Figs. 3(a) and 3(b), scattered Ni agglomerates in 600 and $900{ }^{\circ} \mathrm{C}$ annealed specimens were still observed, which indicates that the complete suppression of the massive $\mathrm{Ni}$ agglomeration in 600 and $900{ }^{\circ} \mathrm{C}$ annealed films is not possible. The number and size of $\mathrm{Ni}$ agglomerates

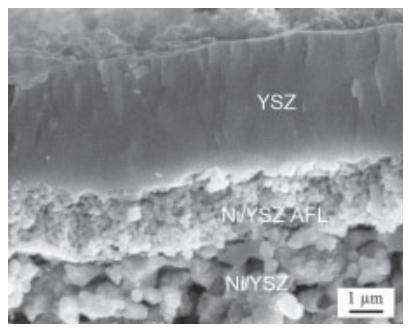

(a)

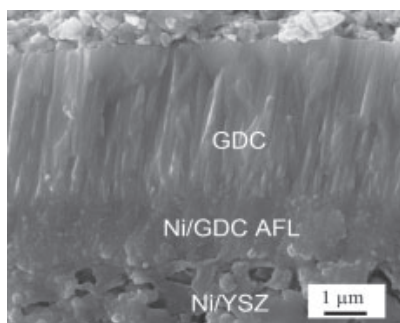

(b)
Fig. 4. Cross sectional SEM images of the SOFCs with nanostructured anode functional layers: Ni/YSZ AFL (NiO 50 vol\%, YSZ electrolyte) (a), $\mathrm{Ni} / \mathrm{GDC}$ AFL (Ni 40 at. \%, GDC electrolyte) (b). SEM images were obtained after cells testing.

in these cases is different. $\mathrm{NiO} / \mathrm{GDC}$ film annealed at $600{ }^{\circ} \mathrm{C}$ contains a large number of small $\mathrm{Ni}$ granules with size of $0.2-0.8 \mu \mathrm{m}$. The granule sizes were measured by the line intercept method in the top-view micrographs with an enhanced contrast, roughly assuming spherical granules. Then the annealing temperature increases up to $900{ }^{\circ} \mathrm{C}$ the number of Ni agglomerates decreases but their size increases up to $0.5-6 \mu \mathrm{m}$. No $\mathrm{Ni}$ agglomeration was observed in $1200{ }^{\circ} \mathrm{C}$ annealed specimen only. Heat treatment at this temperature enhances stability of the ceramic matrix which prevents agglomeration of $\mathrm{Ni}$.

Analysis of cross-sections of Ni/YSZ and Ni/GDC films (Fig. 4) showed that the films acquire a finely porous structure after reduction in hydrogen. In the YSZ-based cell [Fig. 4(a)], a fully dense YSZ electrolyte and a nanostructured Ni/YSZ AFL with a grain size of approximately $100 \mathrm{~nm}$ are formed over the anode support with the micronscale particle sizes. The average grain diameter of PLD deposited NiO-YSZ film after annealing at $1200^{\circ} \mathrm{C}$ and reduction in hydrogen was $177.9 \pm 15.5 \mathrm{~nm} .{ }^{15)}$ AFL makes anode-support surface smoother thus allowing fabrication of a thin electrolyte leading to reduction in resistive losses. The electrochemical activity of a cermet anode with the given microstructure and materials depends on the volume and on the grain size. ${ }^{31)}$ Smaller grains increase the triple phase boundary length and, as a result, the polarization resistance decreases. In the GDC-based cell [Fig. 4(b)], porosity of $\mathrm{Ni} / \mathrm{GDC}$ AFL is smaller. This is explained by lower $\mathrm{Ni}$ content in the layer. The grain size in this layer is in the range of $50-150 \mathrm{~nm}$.

Figure 5 shows cross-sectional SEM images focused on the anode/electrolyte interface of the YSZ- and GDC-based SOFCs without and with anode functional layers. The fine and homogeneous microstructure of the AFLs enhances the continuity of the interface that should reduce interface polarization resistance.

In order to estimate the impact of the $\mathrm{NiO} / \mathrm{YSZ}$ anode functional layer on the fuel cell performance, the currentvoltage $(I-V)$ and current-power $(I-P)$ curves of the anodesupported cells with and without AFL were compared at different temperatures, as shown in Figs. 6(a) and 6(b), respectively. The open circuit voltages $(\mathrm{OCV})$ of both cells were $1.08-1.17 \mathrm{~V}$, depending on the temperature, that is close to the theoretical value of the SOFC. Compared with that of other cells based on PVD deposited thin film electrolytes, ${ }^{32,33)}$ the OCV value is fairly high and stable. The peak 


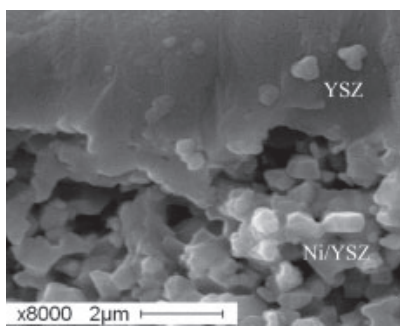

(a)

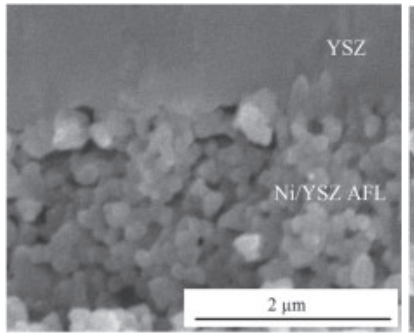

(c)

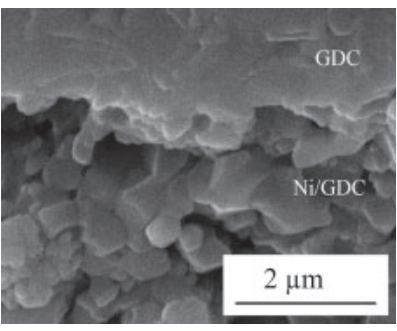

(b)

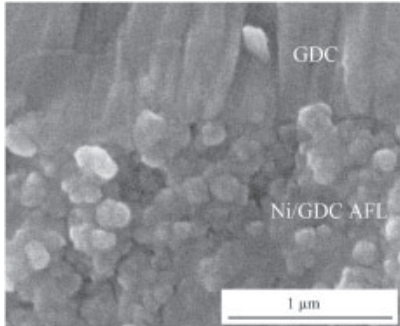

(d)
Fig. 5. Cross-sectional SEM images focused on the interface anode/ electrolyte of the YSZ-based SOFCs without AFL (a), with AFL (c), and GDC-based SOFCs without AFL (b), with AFL (d).

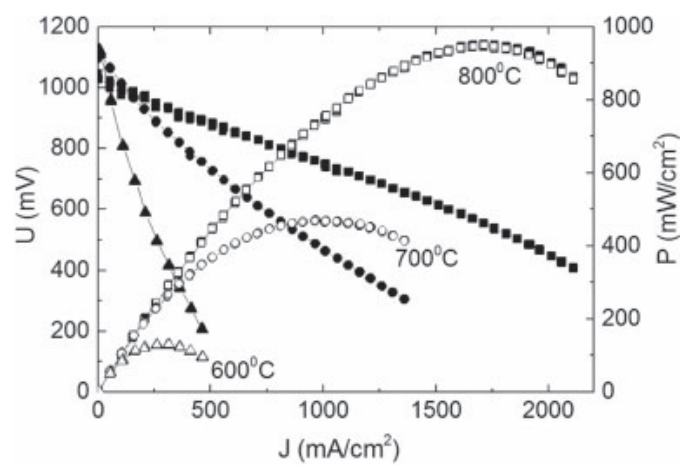

(a)

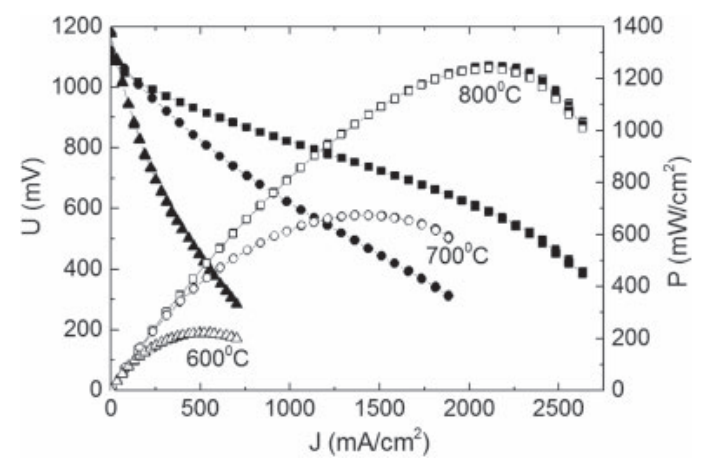

(b)

Fig. 6. $I-V$ and $I-P$ characteristics of the anode-supported SOFC with YSZ electrolyte and LSCF/GDC cathode without (a) and with (b) magnetron sputtered $\mathrm{NiO} / \mathrm{YSZ}$ AFL (NiO $60 \mathrm{vol} \%$ ) measured at temperatures of $600-800^{\circ} \mathrm{C} . \mathrm{H}_{2}-110 \mathrm{sccm}$, air $-375 \mathrm{sccm}$.

power densities of the cell without AFL were 132, 469, and $950 \mathrm{~mW} / \mathrm{cm}^{2}$ at 600,700 , and $800{ }^{\circ} \mathrm{C}$, respectively. Single cell with magnetron sputtered $\mathrm{NiO} / \mathrm{YSZ}$ AFL (NiO 60 vol \%) has peak power densities of 222,675 , and $1240 \mathrm{~mW} / \mathrm{cm}^{2}$ at the same temperatures. Thus, the peak power density of fuel cells with the AFL is $30 \%$ higher at $800{ }^{\circ} \mathrm{C}$ and $68 \%$ higher at $600{ }^{\circ} \mathrm{C}$ than that of the cell without AFL. That is, the effect of AFL on the fuel cell performance is more pronounced at

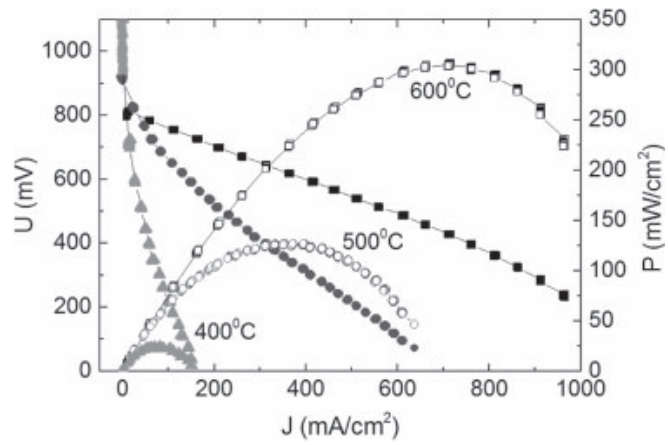

(a)

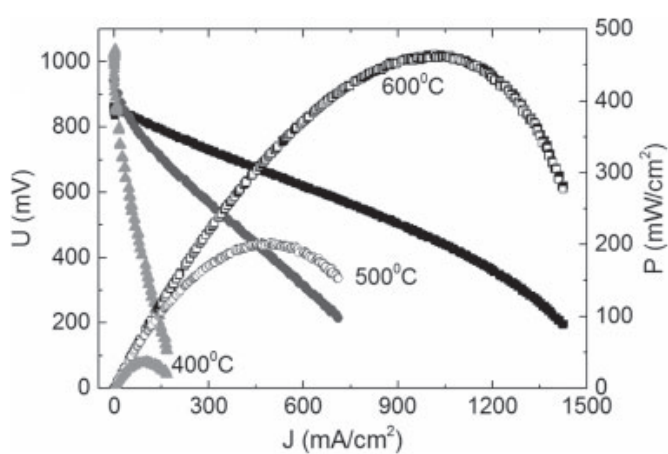

(b)

Fig. 7. $I-V$ and $I-P$ characteristics of the anode-supported SOFC with GDC electrolyte and LSCF/GDC cathode without (a) and with (b) magnetron sputtered $\mathrm{NiO} / \mathrm{GDC}$ AFL (Ni 40 at. \%) measured at temperatures of $400-600^{\circ} \mathrm{C} . \mathrm{H}_{2}-30 \mathrm{sccm}$, air $-300 \mathrm{sccm}$.

low temperatures. No cell failure was observed more than $70 \mathrm{~h}$ of testing.

Figures 7(a) and 7(b) show the $I-V$ behavior of GDCbased samples at various temperatures from 400 to $600{ }^{\circ} \mathrm{C}$. The OCV values of the cell without AFL were 1.134, 0.920, and $0.811 \mathrm{~V}$ at 400,500 , and $600{ }^{\circ} \mathrm{C}$, respectively. The reduction of ceria from $\mathrm{Ce}^{4+}$ to $\mathrm{Ce}^{3+}$ in a reducing atmosphere increases electronic conductivity, which decreases the open-circuit voltage of the cell. But at a temperature below $500{ }^{\circ} \mathrm{C}$ the electronic conductivity of GDC becomes negligible and OCV reaches high values comparable with YSZ electrolyte. The maximum power densities were 25,125 , and $305 \mathrm{~mW} / \mathrm{cm}^{2}$ at 400,500 , and $600{ }^{\circ} \mathrm{C}$, respectively. The $\mathrm{OCV}$ and maximum power densities of the cell with AFL were 1.037, 0.940, $0.861 \mathrm{~V}$ and $40,200,460 \mathrm{~mW} / \mathrm{cm}^{2}$ at 400,500 , and $600{ }^{\circ} \mathrm{C}$, respectively. The increase in power density due to the formation of AFL is 50-60\% depending on the temperature.

The total area-specific resistance (ASR) of YSZ-based cell without AFL calculated from linear fit of $I-V$ curve measured at $800^{\circ} \mathrm{C}$ was $0.27 \Omega \cdot \mathrm{cm}^{2}$. When AFL is applied, the ASR decreased to $0.2 \Omega \cdot \mathrm{cm}^{2}$. The same dependence is observed when using $\mathrm{NiO} / \mathrm{GDC}$ AFL. At $600^{\circ} \mathrm{C}$ AFL deposition results in reduction of ASR from 0.54 to $0.38 \Omega \cdot \mathrm{cm}^{2}$. This implies that a deposited $\mathrm{NiO} / \mathrm{YSZ}$ and $\mathrm{NiO} / \mathrm{GDC}$ AFLs successfully reduced the total cell ASR by $26-30 \%$. The reduction in the total ASR can be attributed to the reduction in the anodic polarization, since an AFL will not affect the cathodic polarization and electrolyte resistance.

One of the main limitations for long-term utilization of the Ni-based anodes is the redox cycling. The volume changes during consistent reduction and re-oxidation cycles may be 


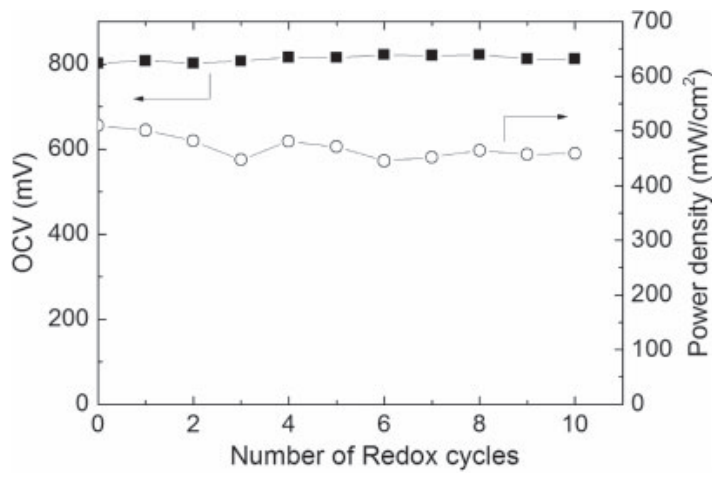

Fig. 8. Open circuit voltage and power density of anode-supported cell with $\mathrm{NiO} / \mathrm{GDC}$ AFL (Ni 40 at. \%) and GDC thin electrolyte during reduction-oxidation cycling at $600^{\circ} \mathrm{C}$.

detrimental for the anode. Furthermore, the volume change subjects the electrolyte under tension and, once cracked, produces leakage between fuel and oxidant gases. ${ }^{34)}$ Fuel cell with magnetron deposited $\mathrm{NiO} / \mathrm{GDC}$ AFL (Ni 40 at. \%) was tested on durability against redox cycling. The open-circuit voltage stayed constant $(0.8-0.82 \mathrm{~V})$ and the power density decreased by $10 \%$ after 10 redox cycles at $600{ }^{\circ} \mathrm{C}$ (Fig. 8). Stable OCV values indicate that there is no cracking of the thin film electrolyte. The rather stable performance is believed to come from the creation of a porous Ni network stabilized by fine GDC particles [Fig. 4(b)]. However, longterm stability of the cell with $\mathrm{NiO} / \mathrm{GDC}$ AFL at $600^{\circ} \mathrm{C}$ should be studied further.

More substantial power decrease was observed after redox cycling of microtubular, anode-supported Ni-YSZ/YSZ/ LSM-YSZ cell at partial oxidation conditions $(22 \%$ oxidation). ${ }^{35)}$ A power output shows decay of about $2 \%$ for each cycle. It was assumed that this degradation is associated with a loss of electrical contact inside the anode as the microstructure is modified during the redox cycling, which could increase the electrical resistance.

Microstructures of the anode/electrolyte interface of the YSZ and GDC-based cells after the cells operation are compared in Fig. 5. The 4- $\mu$ m-thick electrolyte in all cells appears to have sustained its integrity well even after the operation lasted more than $70 \mathrm{~h}$ at working temperature. From this result, we could conclude that the nanostructured $\mathrm{NiO} / \mathrm{YSZ}$ and $\mathrm{NiO} / \mathrm{GDC}$ AFLs are remarkably effective for mechanically supporting a thin film electrolyte in SOFCs.

\section{Conclusions}

$\mathrm{NiO} / \mathrm{YSZ}$ and $\mathrm{NiO} / \mathrm{GDC}$ anode functional layers were deposited by reactive magnetron co-sputtering of $\mathrm{Ni}$ and $\mathrm{Zr}-\mathrm{Y}, \mathrm{Ce}-\mathrm{Gd}$ targets with post deposition annealing in air at $1200{ }^{\circ} \mathrm{C}$. After reduction in hydrogen at $800^{\circ} \mathrm{C}$ films acquire a finely porous structure. The effect of a magnetron sputtered $\mathrm{NiO} / \mathrm{YSZ}$ and $\mathrm{NiO} / \mathrm{GDC}$ AFLs on performance of the anode-supported fuel cells with YSZ and GDC electrolyte was confirmed by electrochemical analyses. The cell performance was increased by $30-60 \%$ depending on the temperature by deposition of $2-3-\mu$ m-thick AFLs as compared to the performance of a cell without it, especially at the lower temperatures. Increase of cells' performance was achieved by reducing the total cell ASR by $26-30 \%$, which is connected with the reduction in the anodic polarization. A thin $\mathrm{NiO} / \mathrm{GDC}$ layer is redox stable. After ten redox cycles at $600{ }^{\circ} \mathrm{C} \mathrm{OCV}$ values are not changed and the power density is decreased by $10 \%$ only.

\section{Acknowledgments}

Investigation of $\mathrm{NiO} / \mathrm{YSZ}$ films was supported by the Russian Science Foundation Grant Number 16-19-00089. $\mathrm{NiO} / \mathrm{GDC}$ films were studied within the framework of the State Assignment of Institute of High Current Electronics.

1) J. H. Park, W. S. Hong, G. C. Kim, H. J. Chang, J. H. Lee, K. J. Yoon, and J. W. Son, J. Electrochem. Soc. 160, F1027 (2013).

2) D. Kennouche, J. Hong, H. S. Noh, J. W. Son, and S. A. Barnett, Phys. Chem. Chem. Phys. 16, 15249 (2014).

3) C. Peters, A. Weber, and E. Ivers-Tiffee, J. Electrochem. Soc. 155, B730 (2008).

4) J. H. Park, S. M. Han, K. J. Yoon, H. Kim, J. Hong, B. K. Kim, J. H. Lee, and J. W. Son, J. Power Sources 315, 324 (2016).

5) A. A. Solovyev, I. V. Ionov, A. V. Shipilova, A. N. Kovalchuk, and M. S. Syrtanov, J. Nanopart. Res. 19, 87 (2017).

6) H. S. Noh, K. J. Yoon, B. K. Kim, H. J. Je, H. W. Lee, J. H. Lee, and J. W. Son, J. Power Sources 247, 105 (2014).

7) A. Evans, J. Martynczuk, D. Stender, C. W. Schneider, T. Lippert, and M. Prestat, Adv. Energy Mater. 5, 1400747 (2015).

8) R. Barfod, A. Hagen, S. Ramousse, P. V. Hendriksen, and M. Mogensen, Fuel Cells 6, 141 (2006).

9) F. J. Garcia-Garcia, F. Yubero, A. R. González-Elipe, S. P. Balomenou, D Tsiplakides, I. Petrakopoulou, and R. M. Lambert, Int. J. Hydrogen Energy 40, 7382 (2015).

10) F. J. Garcia-Garcia, F. Yubero, J. P. Espinós, A. R. González-Elipe, and R. M. Lambert, J. Power Sources 324, 679 (2016).

11) G. Y. Cho, Y. H. Lee, and S. W. Cha, Renewable Energy 65, 130 (2014)

12) S. Jou and T. H. Wu, J. Phys. Chem. Solids 69, 2804 (2008).

13) E. Rezugina, A. L. Thomann, H. Hidalgo, P. Brault, V. Dolique, and Y. Tessier, Surf. Coatings Technol. 204, 2376 (2010).

14) H. S. Noh, J. W. Son, H. Lee, H. S. Song, H. W. Lee, and J. H. Lee, J. Electrochem. Soc. 156, B1484 (2009).

15) H. S. Noh, J. W. Son, H. Lee, H. I. Ji, J. H. Lee, and H. W. Lee, J. Eur. Ceram. Soc. 30, 3415 (2010).

16) W. H. Tanveer, S. Ji, W. Yu, G. Y. Cho, Y. H. Lee, T. Park, Y. Lee, Y. Kim, and S. W. Cha, Curr. Appl. Phys. 16, 1680 (2016).

17) U. P. Muecke, K. Akiba, A. Infortuna, T. Salkus, N. V. Stus, and L. J. Gauckler, Solid State Ionics 178, 1762 (2008).

18) A. Tarancón, Energies 2, 1130 (2009).

19) S. P. Jiang and S. H. Chan, J. Mater. Sci. 39, 4405 (2004).

20) A. A. Solovyev, A. V. Shipilova, I. V. Ionov, A. N. Kovalchuk, S. V. Rabotkin, and V. O. Oskirko, J. Electron. Mater. 45, 3921 (2016).

21) A. Solov'ev, N. Sochugov, A. Shipilova, K. Efimova, and A. Tumashevskaya, Russ. J. Electrochem. 47, 494 (2011).

22) J. Musil, P. Baroch, J. Vlček, K. H. Nam, and J. G. Han, Thin Solid Films 475, 208 (2005)

23) A. A. Solov'ev, N. S. Sochugov, I. V. Ionov, A. V. Shipilova, and A. N. Koval'chuk, Russ. J. Electrochem. 50, 647 (2014).

24) H.-S. Noh, J.-S. Park, J.-W. Son, H. Lee, J.-H. Lee, and H.-W. Lee, J. Am. Ceram. Soc. 92, 3059 (2009).

25) A. Hagen, B. Rasmus, P. V. Hendriksen, Y.-L. Liu, and S. Ramousse, J. Electrochem. Soc. 153, A1165 (2006).

26) W. D. Halstead, Corros. Sci. 15, 603 (1975).

27) J. Sehested, Catal. Today 111, 103 (2006).

28) A. Faes, A. Hessler-Wyser, D. Presvytes, C. G. Vayenas, and J. Van Herle, Fuel Cells 9, 841 (2009).

29) P. Tanasini, M. Cannarozzo, P. Costamagna, A. Faes, J. Van Herle, A. Hessler-Wyser, and C. Comninellis, Fuel Cells 9, 740 (2009).

30) W. G. Bessler, J. Warnatz, and D. G. Goodwin, Solid State Ionics 177, 3371 (2007).

31) H. Fukunaga, M. Ishino, and K. Yamada, Electrochem. Solid-State Lett. 10, B16 (2007).

32) P. Coddet, M.-C. Pera, and A. Billard, Fuel Cells 11, 158 (2011).

33) H. Hidalgo, A.-L. Thomann, T. Lecas, J. Vulliet, K. Wittmann-Teneze, D. Damiani, E. Millon, and P. Brault, Fuel Cells 13, 279 (2013).

34) M. Cassidy, G. Lindsay, and K. Kendall, J. Power Sources 61, 189 (1996).

35) H. Monzón and M. A. Laguna-Bercero, Int. J. Hydrogen Energy 37, 7262 (2012) 